\title{
Hydrogen peroxide induced adenosine diphosphate ribosyl transferase (ADPRT) response in patients with inflammatory bowel disease
}

\author{
M M MARKOWITZ, P ROZEN, R W PERO, M TOBI, AND D G MILLER \\ From the Preventive Medicine Institute-Strang Clinic, New York, NY, USA, Tel Aviv Medical Center, \\ Department of Gastroenterology, Tel Aviv, Israel, and the Wallenberg Laboratory, Division of Molecular \\ Ecogenetics, University of Lund, Sweden
}

Summary The sample population in this initial case control study of the adenosine diphosphate ribosyl transferase (ADPRT) response of inflammatory bowel disease patients included: 23 patients with ulcerative colitis (UC) - active and inactive, 13 patients with Crohn's disease (CD) - active and inactive, 14 first degree relatives of UC and CD patients, and 19 age-matched controls. Adenosine diphosphate ribosyl transferase activity was determined after one hour incubation with $1 \%$ plasma (the constitutive value) or with $1 \%$ plasma and $100 \mu \mathrm{M} \mathrm{H}_{2} \mathrm{O}_{2}$ (the activated value) with the resulting difference designated as the induced value. Statistically significant decrease in ADPRT activity was found for the constitutive, activated and induced values in human mononuclear leucocytes of $U C$ and CD patients, compared with controls. The values in the first degree relatives of UC and CD patients were not significantly different from either the control or disease populations, indicating an intermediate ADPRT response. These results may be related to the nature of the immunological response of IBD patients and comparable with similar findings in other diseases with known DNA repair deficiencies - for example, colon cancer.

Ulcerative colitis (UC) and Crohn's disease (CD) are both inflammatory bowel diseases (IBD) whose origins remain obscure..$^{1-7}$ Although they are usually differentiated by their clinical manifestations, these diseases have a number of common features; these include an incidence of colorectal cancer greater than that found in the general population ${ }^{3-10}$ and an increased familial incidence of IBD. ${ }^{1-4}$ In addition, immunological perturbations occur during the active state of the disease $e^{1-711-15}$ and although they may not be the initiating factors, they are associated with the continued chronic inflammation found in both UC and $C D$ patients.

Our interest focused on the DNA repair response of IBD patients because the above features paralleled those found in our previous studies. These showed that a reduced level of DNA repair, as measured by the rate of unscheduled DNA synthesis

Address for correspondence: Dr M M Markowitz. Preventive Medicine Institute - Strang Clinic, 55 East 34 Street, New York, NY 10016, USA.

Received for publication 1 July 1988.
(UDS) and adenosine diphosphate ribosyl transferase (ADPRT) induction, occurred in patients with a history of colorectal cancer as well as in individuals genetically predisposed to colorectal cancer and in patients with colonic adenomatous polyps. ${ }^{16-19}$ Other diseases which are known to be genetically predisposed to DNA repair deficiencies such as xeroderma pigmentosum and ataxia telangiectasia ${ }^{20}$ also show a significant cancer predisposition.

The present study was initiated to determine the DNA repair capacity of IBD patients as measured by the inducibility of the repair related enzyme, ADPRT. This enzyme transfers the adenosine diphosphate moiety of NAD + to various acceptor proteins in the form of [ADP-ribose $]_{n}$ monomers and polymers. Although the precise function of the ADPRT enzyme is not completely understood, it has been shown to function during the process of DNA excision repair after the induction of DNA damage $^{21-23}$ and also during the process of cellular differentiation, ${ }^{24}$ including the response of human lymphocytes to mitogenic stimulation. ${ }^{25}$ 
Hydroperoxides and other reactive oxygen species are known to be involved in the processes of mutagenesis, aging and tumour promotion ${ }^{26-28}$ and, in addition, have also been shown to elicit DNA repair responses..$^{24}$ Creating an environment of oxidative stress - that is, the exposure of cells to oxygen radicals - may well parallel the condition found in IBD patients whose intestinal mucosa contains increased numbers of monocytes and macrophages which are known to kill invading bacteria by sudden oxidative bursts. ${ }^{30}$

As related below, a statistically significant reduction in ADPRT was found in HML of IBD patients after incubation with either $1 \%$ plasma or $100 \mu \mathrm{M}$ $\mathrm{H}_{2} \mathrm{O}_{2}$ in $1 \%$ plasma.

\section{Methods}

PATIENTS

The patients included in this investigation were all selected for their past or present history of inflammatory bowel disease. Others included in this study were first degree, clinically disease free, relatives of IBD patients and a control population of disease free individuals with no family history of IBD. Sampling of patients occurred between April and June, 1987 at the Tel Aviv Medical Center, Israel. At the initial time of sampling patient category was unknown. These individuals were separated into four categories: (1) Controls - those without IBD and no familial history of the disease, $n=19$; (2) Patients with ulcerative colitis (active and inactive), $n=23$; (3) Patients with Crohn's disease (active and inactive), $n=13$; (4) First degree relatives of ulcerative colitis $(n=9)$ and Crohn's disease $(n=5)$ patients (total $n=14$ ).

\section{SAMPLING PROCEDURES}

The isolation technique for HML has been documented elsewhere." Samples of peripheral venous blood $(-30 \mathrm{ml})$ were collected in heparinised Vacutainers $^{\mathrm{Tm}}$, centrifuged at $100 \times g$ for 10 minutes, and the platelet rich plasma, upper layer, was removed. Sterile physiologic saline solution was added to the lower cellular layer to restore it to the original blood volume. The sample was then layered onto Ficoll-Isopaque solution and centrifuged at $400 \times g$ for 25 minutes. Mononuclear leucocytes were isolated from the upper phase at the interface, washed with physiologic saline and quantified in a haemacytometer. Plasma was centrifuged at $400 \times g$ for 25 minutes to deplete its platelet content.

TREATMENT OF HML WITH $\mathrm{H}_{2} \mathrm{O}_{2}$ Human mononuclear leucocytes $\left(0.5 \times 10^{\%} /\right.$ ADPRT assay) were suspended in physiologic saline supple- mented with $1 \%$ platelet depleted autologous plasma in a total volume of $550 \mu \mathrm{l} . \mathrm{H}_{2} \mathrm{O}_{2}$, dissolved in saline, was added to give a final concentration of $100 \mu \mathrm{M}$. The resulting mixture was incubated for one hour at $37^{\circ} \mathrm{C}$. Cells were then pelletted by centrifuging before the determination of the activated ADPRT value. Another set of samples without $\mathrm{H}_{2} \mathrm{O}_{2}$ was kept under the same culture conditions to determine the background ADPRT value which is designated as the constitutive value. The resulting difference between these two values is termed the induced value.

\section{ADPRT ASSAY}

We have published our procedure in detail elsewhere..$^{32}$ Briefly, duplicate cultures of $0.5 \times 10^{6}$ cells were pelletted at $4^{\circ} \mathrm{C}$ and permeabilised in $1.5 \mathrm{ml}$ hypotonic buffer solution $(10 \mathrm{mM}$ Tris- $\mathrm{HCl}, 1 \mathrm{mM}$ EDTA, $30 \mathrm{mM}$ 2-mercaptoethanol, $4 \mathrm{mM} \mathrm{MgCl}_{2}$,

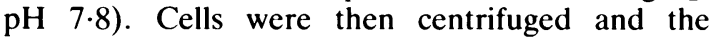
permeabilisation buffer removed. Adenosine diphosphate ribosyl transferase was estimated after 15 minutes at $30^{\circ} \mathrm{C}$ in a reaction mixture containing 0.7

Table 1 Control group $(n=19)$. ADPRT values (cpm $/ 0 \cdot 5 \times 10^{\prime \prime}$ cells) of $H M L$ with and without treatment with $\mathrm{H}_{2} \mathrm{O}_{2}(100 \mu \mathrm{M})$ for one hour at $37^{\circ} \mathrm{C}$ in the presence of $1 \%$ platelet-poor plasma

\begin{tabular}{|c|c|c|c|c|c|}
\hline Patient code & Age & $\operatorname{Sex}$ & $\begin{array}{l}\text { Constitutive } \\
\text { ADPRT }\end{array}$ & $\begin{array}{l}\text { Activated } \\
\text { ADPRT }\end{array}$ & $\begin{array}{l}\text { Induced } \\
\text { ADPRT }\end{array}$ \\
\hline 16 & 40 & $\mathbf{M}$ & 901 & 2576 & 1675 \\
\hline 20 & 45 & $\mathbf{M}$ & 698 & 4023 & 3325 \\
\hline 21 & 27 & $\mathbf{M}$ & 955 & 2879 & 1924 \\
\hline 22 & 34 & $\mathrm{~F}$ & 1224 & 6195 & 4971 \\
\hline 23 & 46 & $\mathrm{~F}$ & 706 & 3111 & 2405 \\
\hline 24 & 36 & $\mathbf{M}$ & 1039 & 2934 & 1895 \\
\hline 25 & 55 & $\mathbf{M}$ & 1526 & 6346 & 4820 \\
\hline 32 & 32 & $F$ & 993 & 4017 & 3024 \\
\hline 38 & 45 & $\mathbf{M}$ & 623 & 3944 & 3321 \\
\hline 45 & 38 & $F$ & 588 & 4146 & 3558 \\
\hline 46 & 30 & $\mathbf{M}$ & 539 & 3482 & 2943 \\
\hline 47 & 71 & $\mathbf{M}$ & 708 & 3001 & 2393 \\
\hline 49 & 42 & $\mathbf{M}$ & 691 & 4691 & 4000 \\
\hline 68 & 37 & $\mathrm{~F}$ & 494 & 2548 & 2054 \\
\hline 69 & 47 & $F$ & 928 & 3342 & 2414 \\
\hline 70 & 34 & $\mathbf{M}$ & 681 & 2352 & 1671 \\
\hline 76 & 53 & $\mathbf{M}$ & 626 & 2365 & 1739 \\
\hline 77 & 36 & $\mathbf{M}$ & 394 & 2813 & 2419 \\
\hline 78 & 34 & $\mathbf{M}$ & 506 & 3870 & 3364 \\
\hline $\begin{array}{l}\operatorname{Mean}(\mathrm{SE}) \\
\qquad(\mathrm{n}=19)\end{array}$ & \multicolumn{2}{|c|}{$41 \cdot 2(2 \cdot 4)$} & $780(64 \cdot 4)$ & $3612(264)$ & $2838(230)$ \\
\hline $\begin{array}{l}\text { Student's } t \text { test } \\
v \text { all UC and } \\
\text { CD patients } \\
(n=36)\end{array}$ & \multicolumn{2}{|c|}{$\begin{array}{c}42(3 \cdot 0) \\
\quad p>0 \cdot 5\end{array}$} & $\begin{array}{c}598 \cdot 6(32) \\
p=0 \cdot(006\end{array}$ & $\begin{array}{c}2652 \cdot 4(190) \\
p=0 \cdot(004\end{array}$ & $\begin{array}{c}2053 \cdot 2(174) \\
p=0 \cdot(01\end{array}$ \\
\hline $\begin{array}{l}\text { Student's } t \text { test } \\
v \text { first degree } \\
\text { relatives of } \\
\text { UC and CD } \\
\text { patients } \\
(n=14)\end{array}$ & \multicolumn{2}{|c|}{$\begin{array}{r}48 \cdot 9(4 \cdot 3) \\
p>0 \cdot 09\end{array}$} & $\begin{array}{r}776(103) \\
p=0.44\end{array}$ & $\begin{array}{c}2928(204) \\
p=0 \cdot(66\end{array}$ & $\begin{array}{c}2152(184) \\
p=(0 \cdot(03\end{array}$ \\
\hline
\end{tabular}


Table 2a Ulcerative colitis group ( $n=23)$. ADPRT values $\left(\mathrm{cpm} / 0 \cdot 5 \times 10^{n}\right.$ cells) of $H M L$ with and without treatment with $\mathrm{H}_{2} \mathrm{O}_{2}(100 \mu \mathrm{M})$ for one hour at $37^{\circ} \mathrm{C}$ in the presence of platelet depleted plasma

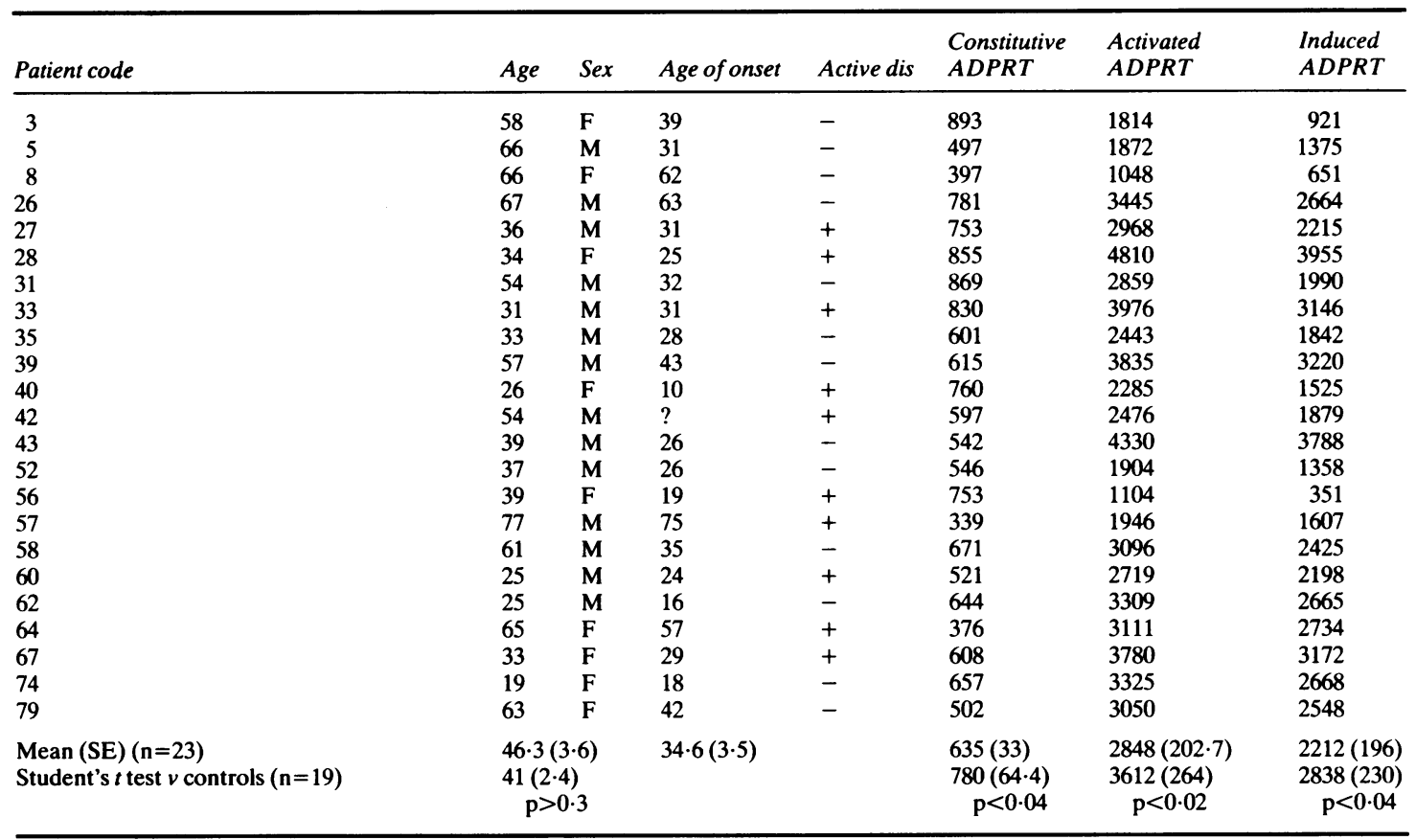

$\mu \mathrm{Ci}$ [Adenosine $2,8-{ }^{3} \mathrm{H}$ ]-NAD ${ }^{+}(27 \cdot 1 \mathrm{Ci} / \mathrm{mmol})$. The data were recorded as trichloracetic acid precipitable cpm per $0.5 \times 10^{6}$ cells after collection onto nitrocellulose filters. Radioactivity was quantified by scintillation counting over a 10 minute period. The degree of quenching was low and consistent between experimental groups. Measurements were made in duplicate and the paired values were within $10 \%$ of the mean.

STATISTICAL ANALYSIS

Student's $t$ test was used for the data analysis found in Tables 1-3. Data analysis in Table 4 was carried out on a Data General MV2000 minicomputer with a software package (version 5) from the SAS Institute, Cary, NC.

Table 2b Crohn's disease group $(n=13)$

\begin{tabular}{|c|c|c|c|c|c|c|c|}
\hline Patient code & Age & $\operatorname{Sex}$ & Age of onset & Active dis & $\begin{array}{l}\text { Constitutive } \\
\text { ADPRT }\end{array}$ & $\begin{array}{l}\text { Activated } \\
\text { ADPRT }\end{array}$ & $\begin{array}{l}\text { Induced } \\
A D P R T\end{array}$ \\
\hline 13 & 59 & $\mathbf{M}$ & 40 & - & 510 & 2611 & 2101 \\
\hline 17 & 37 & $\mathbf{M}$ & 22 & + & 594 & 4054 & 3460 \\
\hline 18 & 43 & $F$ & 40 & + & 838 & 3320 & 2482 \\
\hline 19 & 69 & F & 69 & - & 723 & 2260 & 1537 \\
\hline 29 & 40 & F & 20 & - & 966 & 3739 & 2773 \\
\hline 44 & 24 & $\mathbf{F}$ & 20 & - & 356 & 986 & 630 \\
\hline 50 & 19 & $\mathbf{M}$ & 17 & - & 294 & 443 & 149 \\
\hline 51 & 40 & F & 30 & - & 499 & 1738 & 1239 \\
\hline 53 & 20 & $\mathbf{M}$ & 18 & + & 673 & 3465 & 2792 \\
\hline 61 & 24 & F & 23 & - & 197 & 362 & 165 \\
\hline 66 & 26 & $\mathbf{M}$ & 23 & + & 493 & 1271 & 778 \\
\hline 75 & 48 & $\mathbf{F}$ & 18 & - & 572 & 4193 & 3621 \\
\hline 80 & 50 & $\mathbf{F}$ & 34 & + & 227 & 1518 & 1291 \\
\hline Mean $(S E)(n=13)$ & \multirow{3}{*}{\multicolumn{2}{|c|}{$\begin{array}{c}38 \cdot 4(4 \cdot 3) \\
41(2 \cdot 4) \\
p>0 \cdot 5\end{array}$}} & \multirow{3}{*}{\multicolumn{2}{|c|}{$28 \cdot 8(4 \cdot 0)$}} & $534(64)$ & $2305(376 \cdot 3)$ & $1771(330)$ \\
\hline Student's $t$ test $v$ controls $(n=19)$ & & & & & $780(64 \cdot 4)$ & $3612(264)$ & $2838(230)$ \\
\hline & & & & & $\mathrm{p}<0.01$ & $\mathrm{p}=0.006$ & $p=0.01$ \\
\hline
\end{tabular}


Table 3 First degree relatives of UC and CD patients $(n=14)$. ADPRT values $(\mathrm{cpm} / 0 \cdot 5 \times 106$ cells) of HML with and without treatment with $\mathrm{H}_{2} \mathrm{O}_{2}(100 \mu \mathrm{M})$ for one hour at $37^{\circ} \mathrm{C}$ in the presence of $1 \%$ platelet-depleted plasma

\begin{tabular}{|c|c|c|c|c|c|c|}
\hline Patient code & Age & Sex & Relative & $\begin{array}{l}\text { Constitutive } \\
\text { ADPRT }\end{array}$ & $\begin{array}{l}\text { Activated } \\
\text { ADPRT }\end{array}$ & $\begin{array}{l}\text { Induced } \\
\text { ADPRT }\end{array}$ \\
\hline 30 & 37 & $F$ & UC & 769 & 2504 & 1735 \\
\hline 34 & 72 & $\mathbf{M}$ & UC & 670 & 3445 & 2775 \\
\hline 36 & 45 & $\mathbf{M}$ & $\mathrm{CD}$ & 906 & 3086 & 2180 \\
\hline 37 & 63 & $\mathrm{~F}$ & UC & 416 & 1201 & 785 \\
\hline 41 & 51 & $\mathbf{M}$ & UC & 791 & 3201 & 2410 \\
\hline 54 & 33 & $\mathbf{M}$ & UC & 614 & 1892 & 1278 \\
\hline 55 & 75 & $\mathbf{M}$ & UC & 691 & 3171 & 2480 \\
\hline 59 & 38 & $\mathbf{M}$ & UC & 695 & 2841 & 2146 \\
\hline 63 & 70 & $\mathbf{F}$ & $\mathrm{CD}$ & 457 & 2162 & 1705 \\
\hline 65 & 62 & $\mathrm{~F}$ & $\mathrm{CD}$ & 529 & 3592 & 3063 \\
\hline 71 & 35 & $F$ & $\mathrm{CD}$ & 586 & 3984 & 3398 \\
\hline 72 & 36 & $\mathbf{M}$ & UC & 978 & 3292 & 2314 \\
\hline 73 & 39 & $\mathbf{M}$ & $\mathrm{UC}$ & 2000 & 3704 & 1704 \\
\hline Mean $(\mathrm{SE})(n=14)$ & \multicolumn{3}{|c|}{$48 \cdot 9(4 \cdot 3)$} & $776(103)$ & $2928(204)$ & $2152(184)$ \\
\hline Student's $t$ test $v$ UC patients $(\mathrm{n}=23)$ & \multicolumn{3}{|c|}{$\begin{array}{c}46.3(3.6) \\
p>0.5\end{array}$} & $\begin{array}{l}635(33) \\
p=0 \cdot 13\end{array}$ & $\begin{array}{c}2848(202 \cdot 7) \\
p=0.69\end{array}$ & $\begin{array}{c}2212(196) \\
p=0.67\end{array}$ \\
\hline Student's $t$ test $v$ CD patients $(\mathbf{n}=13)$ & \multicolumn{3}{|c|}{$38 \cdot 4(4 \cdot 3)$} & $\begin{array}{l}534(64) \\
p=0.06\end{array}$ & $\begin{array}{c}2305(376 \cdot 3) \\
p=0 \cdot 15\end{array}$ & $\begin{array}{c}1771(330) \\
p=0 \cdot 31\end{array}$ \\
\hline
\end{tabular}

\section{Results}

The IBD patients in this study showed a broad range regarding the age of onset and the duration of their disease. Controls were age matched for the upper and lower limits of the disease population. No statistically significant difference with regard to age was found between the controls and any of the other patient categories (Tables 1-4).

The results of $\mathrm{H}_{2} \mathrm{O}_{2}$ influenced ADPRT in HML are shown in Tables 1-3. When control individuals (Table 1) are compared by Student's $t$ test to the UC population (Table 2a), a statistically significant difference is shown for their constitutive activated ADPRT and induced values; these being $p=0.04$, 0.02 , and 0.04 , respectively (Table $2 a$ ).

An even greater level of significance is found when controls are compared with Crohn's disease patients (Table 2b) where the constitutive, activated ADPRT and induced values are $p=0.01,0.006$, and 0.01 , respectively (Table $2 b$ ). In addition, significant values are also obtained when the entire IBD population (Tables $2 \mathrm{a}, \mathrm{b}$ ) is matched against the controls; $\mathrm{p}=0.006,0.004$, and 0.01 (Table 1 ).

On the other hand, first degree relatives of UC and CD patients do not show the same degree of divergence from the control values as those individuals manifesting the disease (Table 1). Their ADPRT measurements vary between being not statistically significant, constitutive value $-\mathrm{p}=0.44$; significant, induced value $-p=0 \cdot 3$; and of borderline significance, activated value $-p=0 \cdot 06$. They, therefore, do not approach the degree of difference found when either disease group is compared with the control population. Furthermore, no level of significance was obtained for either disease group when compared to the first-degree relative population (Table 3 ). They appear, therefore, as a group whose level of ADPRT induction lies between the control and disease populations. This may well indicate a population enriched for suppressed ADPRT responses.

It was also determined that there was no statistical difference between the values found for patients with active IBD versus those whose disease was in remission.

Finally, when the influences of the variables disease, age, sex, and family history were analysed by multivariate analysis of variance, it was found that the only significant influence on variance was the presence or absence of disease $(p=0 \cdot 01)$ (Table 4$)$.

\section{Discussion}

Non-specific inflammatory bowel disease consisting of ulcerative colitis and Crohn's disease is most commonly encountered in Northwestern Europe and

Table 4 Multivariate analysis of UC and CD groups $\mathrm{v}$ control group

\begin{tabular}{lll}
\hline Category & Fvalue & $p$ Value \\
\hline Disease & 6.94 & $0 \cdot 01$ \\
Age & 0.03 & $0 \cdot 86$ \\
Sex & 0.08 & $0 \cdot 78$ \\
Family HX & 1.66 & $0 \cdot 20$ \\
\hline
\end{tabular}

The presence of disease is the only significant variable in relation to the induction of ADPRT. 
North America ${ }^{33-36}$ and appears to be extremely prevalent among members of the Jewish populations of these regions. ${ }^{4437}$ In the United States, IBD (especially CD) is found to be more common among Jewish people ${ }^{4}$ and a study in Malmo, Sweden found the incidence of $C D$ to be five times greater for Jews than for non-Jews. ${ }^{38}$

The present study was designed to investigate a Jewish population of IBD patients in Tel Aviv, Israel. These patients were of interest as they showed both active and inactive forms of IBD and because the clinical course of their disease had been well documented - for example, periods of remission and age of onset (Tables 2 and 3 ).

The results as shown in Tables $1-4$ clearly show that IBD patients, both $\mathrm{UC}$ and $\mathrm{CD}$, have a marked reduction in ADPRT activity. Furthermore, the decrease in the ADPRT activity of the first degree relative population in comparison with the controls may indicate that this population is also affected by similar immunological perturbations, although to a lesser degree, than their $\mathrm{UC}$ and $\mathrm{CD}$ relatives. These data parallel our findings of DNA repair deficiencies in colon cancer patients, individuals predisposed to colon cancer and in patients with adenomatous polyps. ${ }^{16}{ }^{17} 19$ Inflammatory bowel disease patients are also similar to these individuals in that they show familial and genetic patterns of disease inheritance and have a higher than normal frequency of colorectal cancer. .10 $^{39-43}$.

In addition, IBD is associated with a variety of poorly defined immunological abnormalities which because of their nature and severity may have a direct affect on the degree of ADPRT activity. These immunological changes alter the gastrointestinal tract - for example, make it a more pro-oxidative environment, and may be responsible for initiating the long term, chronic phases of the disease. ${ }^{12}$ Changes in the cellular environment may also be responsible for the altered ADPRT levels found in IBD patients.

Various types of cells derived from the immune system are prominent in the intestinal mucosa of IBD patients. ${ }^{153044}$ These include $T$ cells, activated T killer cells, macrophages, monocytes, polymorphonuclear leucocytes, basophils, and eosinophils. ${ }^{5}$ All of these cell types may participate in the production of tissue damage and inflammatory gastrointestinal reactions.

Furthermore, Nielson et al ${ }^{45}$ have shown that there is an abnormality in arachidonic acid metabolism in patients with chronic IBD. Activated neutrophils were shown to have an increased production of $\mathrm{LTB}_{4}$ which is considered to be the major proinflammatory metabolite of arachidonic acid metabolism by polymorphonuclear leucocytes. The increased production of $\mathrm{LTB}_{4}$ and other lip- oxygenase products of arachidonic acid may, therefore, support the constant climate of inflammation and tissue degradation that is found in patients with IBD. 4546

This hypothesis is further supported by the recent work of Nishida $e$ t al who showed that the colonic mucosa of patients with active UC demonstrates a statistically significant increase in arachidonic acid composition. ${ }^{47}$ These findings coincide with the observed increase in the products of arachidonic acid metabolism - for example, leucotriene $\mathrm{B}_{4}$ and 5hydroxyeicosatetra-enoic acid (5-HETE) - found in patients with active UC. ${ }^{47}+8$

Inflammatory bowel disease patients also show a greater production and release of acid hydrolases in their peripheral blood monocytes in vitro as compared with controls. ${ }^{31}$ Under the influence of immunological stimuli, monocytes are thought to be releasing lysosomal enzymes, thereby perpetuating the intestinal inflammation. ${ }^{6}$

Finally, protease effects on ADPRT have also been reported and may contribute to the molecular mechanism behind IBD. ${ }^{49}$ The inhibition of protease and ADPRT synthesis is known to be associated with a reduction in malignant transformation. In addition, both proteases and ADPRT can be inhibited by similar compounds - for example, benzamide - which suggests that proteases may be involved in the formation and action of poly(ADP-ribose). ${ }^{49}$

In conclusion, we have shown a deficient ADPRT response in the HML of IBD patients and as ADPRT activation relates directly to immune responsiveness, ${ }^{2550}$ this study may afford an approach to the molecular mechanism behind the initiation of IBD.

The authors wish to thank the staff in the Departments of Gastroenterology and Pulmonary and Allergic Diseases at Ichilov hospital for their assistance during the course of this study. We particularly thank Dr Jochanan Peled of Ichilov hospital for his technical support and Dr Desmond Johnson of the Preventive Medicine Institute/Strang Clinic for his assistance with statistical determinations. The project was supported financially by John W Kluge and the Cancer Protection Fund at PMI-Strang Clinic. Additional funding was provided by the Workers Protection Fund in Sweden.

\section{References}

1 Strober W, James SP. The immunological basis of inflammatory bowel disease. J Clin Immunol 1986; 6: 415-32.

2 Kirsner JB. The idiopathic inflammatory bowel diseases. Arch Dermatol 1982; 118: 280-2.

3 Kirsner JB. Inflammatory bowel diseases: considerations of etiology and pathogenesis. Am J Gastroenterol 1978; 69: 253-71. 
4 Kirsner JB, Shorter RG. Recent developments in nonspecific inflammatory bowel disease. $N$ Engl J Med 1982; 306: 237-46.

5 Kagnoff MF. Inflammatory bowel disease - The search for an etiology. In: Rachmilewitz D, ed. Inflammatory Bowel Disease. Proceedings of the International Symposium of Inflammatory Bowel Diseases, Jerusalem, Sept 7-9, 1981. The Hague: Martinus Nijhoff Publishers, 1982: 59-67.

6 Shorter RG. Idiopathic inflammatory bowel disease (IBD): a review of immunological mechanisms. In: Rachmilewitz D, ed. Inflammatory Bowel Disease. Proceedings of the International Symposium of Inflammatory Bowel Diseases, Jerusalem, Sept 7-9, 1981. The Hague: Martinus Nijhoff Publishers, 1982: 68-79.

7 Kraft SC, Kirsner JB. The immunology of ulcerative colitis and Crohn's disease: clinical and humoral aspects. In: Kirsner JB and Shorter RB, eds. Inflammatory bowel disease. Philadelphia: Lea and Febiger, 1980: 86-120.

8 Hamilton SR. Colorectal carcinoma in patients with Crohn's disease. Gastroenterology 1985; 89: 398-407.

9 Greenstein AF, Sachar DB. Cancer in Crohn's disease. In: Allan RN, et al eds. Inflammatory bowel diseases. Edinburgh: Churchill Livingstone, 1983: 332-7.

10 Butt FH, Price A, Williams CB. Dysplasia and cancer in ulcerative colitis. In: Allan RN, et al, eds. Inflammatory bowel diseases. Edinburgh: Churchill Livingstone, 1983: 140-53.

11 Elson CO, Kagnoff MF, Fiocchi C, Befus AD, Targon ST. Intestinal immunity and inflammation: recent progress. Gastroenterology 1986; 91: 746-68.

12 Jewell DP, Patel C. Immunology of inflammatory bowel disease. Scand J Gastroenterol 1985; 114 [suppl]: 119-26.

13 Das DM, Kadona Y, Nagai T. Ulcerative colitis: an autoimmune disease. In: Rachmilewitz D, ed. Inflammatory bowel disease. Proceedings of the International Symposium of Inflammatory Bowel Diseases, Jerusalem, Sept 7-9, 1981. The Hague: Nijhoff Publishers, 1982: 80-95

14 Kemler BJ, Alpert E. Inflammatory bowel disease: a study of cell mediated cytotoxicity for isolated human colonic epithelial cells. Gut 1980; 21 : 353-9.

15 Broberger O, Perlmann P. Autoantibodies in human ulcerative colitis. J Exp Med 1959; 110: 657-74.

16 Pero RW, Miller DG, Lipkin M, et al. A reduced capacity for DNA repair synthesis in mononuclear blood cells from patients with either a history of or the hereditary predisposition for colorectal cancer. $J$ Natl Cancer Inst 1983; 70: 867-75.

17 Pero RW, Ritchie M, Winawer SJ, Markowitz MM, Miller DG. Analysis of unscheduled DNA synthesis in mononuclear leucocytes from patients with colorectal polyps. Cancer Res 1985; 45: 3388-91.

18 Pero RW, Heim S, Bryngelsson C. Lower rates of thymidine incorporation into DNA skin fibroblasts from patients with adenomatosis of the colon and rectum. Carcinogenesis 1986; 7: 541-5.

19 Markowitz M, Johnson DB, Pero RW, Winawer SJ, Miller DG. Effects of cumene hydroperoxide on adenosine diphosphate ribosyl transferase in mononuclear leucocytes of patients with adenomatous polyps of the colon. Carcinogenesis 1988; 9: 349-55.
20 Setlow RB. Repair deficient human disorders and cancer. Nature 1978; 271: 713-7.

21 Ueda K. ADP-ribosylation. Ann Rev Biochem 1985; 54: 73-100.

22 Miwa M, Kuto M, Iijima $\mathrm{H}$, et al. Poly(ADP-ribose): structure, quantification and biological significance. In: Miwa M, et al, eds. ADP-Ribosylation, DNA repair and cancer. Tokyo: Japan Sci Sco Press/Uttrecht: VNU Science Press, 1983: 27.

23 Purnell MR, Stone PR, Whish WJD. ADP-ribosylation of nuclear proteins. Biochem Soc Trans 1980; 8: 215-27.

24 Farzaneh F, Zalin R, Brill D, Shall S. DNA strand breaks and ADP-ribosyl transferase activation during cell differentiation. Nature 1982; 300: 362-6.

25 Johnstone AP, Williams GT. Role of DNA breaks and ADP-ribosyl transferase activity in eukaryotic differentiation demonstrated in human lymphocytes. Nature 1982; 300: 368-70.

26 Sohal RS, Allen RG. Relationship between oxygen metabolism, aging and development. In: Pryor WD, ed. Advances in free radical biology and medicine. Vol 2. New York: Pergamon Press, 1986: 117-60.

27 Troll $\mathrm{W}$, Wiesner $\mathbf{R}$. The role of oxygen radicals as a possible mechanism of tumor promotion. Ann Rev Pharmacol Toxicol 1985; 25: 509-28.

28 Moody CS, Hassan HM. Mutagenicity of oxygen free radicals. Proc Natl Acad Sci USA 1982; 79: 2855-9.

29 Morganstern R, Pero RW, Miller DG. Induction of unscheduled DNA synthesis in mononuclear leucocytes by oxidative stress. In: Jollow D, Snyder R, eds. Biological reactive intermediates. Vol III. New York: Plenum Publishing Company, 1986: 819-23.

30 Bartnik W, Shorter RG. Inflammatory bowel disease: immunological developments. In: Berk JE, ed. Developments in digestive diseases. Philadelphia: Lea and Febiger, 1980: 109-27.

31 Pero RW, Bryngelsson C, Mitelman F, Thulin T, Norden A. High blood pressure related to carcinogen induced unscheduled DNA synthesis, DNA carcinogen binding, and chromosome aberrations in human lymphocytes. Proc Natl Acad Sci USA 1976; 73: 2496500.

32 Pero RW, Jonsson GG, Persson L. Unscheduled DNA synthesis induced by $\mathrm{N}$-acetoxy-z-acetylaminofluorene is not sensitive to regulation by ADP-ribosyl transferase. Chem Biol Interact 1983; 47: 265-75.

33 Mendeloff AI. The epidemiology of idiopathic inflammatory bowel disease. In: Kirsner JB, Shorter RG, eds. Inflammatory bowel diseases. Philadelphia: Lea and Febiger, 1980: 5-22.

34 Schacter H, Kirsner JB. Crohn's disease of the gastrointestinal tract. New York: John Wiley and Sons, 1980: $12-6$.

35 Langman MJS, Burnham WR. Epidemiology of inflammatory bowel disease. In: Allan RN, et al, eds. Inflammatory bowel diseases. Edinburgh: Churchill Livingstone, 1983: 17-23.

36 Calkins BM, Lilienfeld AM, Garland CF, Mendeloff AI. Trends in incidence rates of ulcerative colitis and Crohn's disease. Dig Dis Sci 1984; 29: 913-20.

37 Gilat T, Grossman A, Fireman Z, Rozen P. Inflammatory Bowel Diseases in Jews. Front Gastroenterol Res 1986; 11: 135-40. 
38 Brahme F, Linstrome C, Wenckert A. Crohn's disease in a defined population: an epidemiological study of incidence, prevalence, mortality and secular trends in the city of Malmo, Sweden. Gastroenterology 1975; 69: $342-51$.

39 Lewkonia RM, McConnell RB. Progress report: familial inflammatory bowel disease-heredity or environment? Gut 1976; 17: 235-43.

40 Fielding JF. The relative risk of inflammatory bowel disease among parents and siblings of Crohn's disease patients. J Clin Gastroenterol 1986; 8: 655-7.

41 Alstead EM, McConnell RB. Genetic aspects of inflammatory bowel disease and gastrointestinal cancer. Acta Gastro-Enterol Belg 1884; 47: 139-48.

42 McConnell RB. Genetics of inflammatory bowel disease. In: Allan RN, ed. Inflammatory bowel diseases. Edinburgh: Churchill Livingstone, 1983: 8-16.

43 Schlosstein L, Terasaki PI, Bluestone R, et al. High association of HLA antigen W27 with ankylosing spondylitis. N Engl J Med 1973; 288: 704-6.

44 Beeken WL, Gump DW. Phagocytic function of intestinal macrophages in inflammatory bowel disease. In: Burakoff $\mathrm{R}$, ed. IBD news of the national foundation for ileitis and colitis. New York: The National Foundation for Ileitis and Colitis, 1986: 4.
45 Nielson OH, Ahnfelt-Ronne I, Elmgreen J. Abnormal metabolism of arachidonic acid in chronic inflammatory bowel disease: enhanced release of leucotriene B4 from activated neutrophils. Gut 1987; 28: 181-5.

46 Flohe L, Beckmann R, Giertz H, Loschen G. Oxygencentered free radicals as mediators of inflammation. In: Sies H, ed. Oxidative stress. London: Academic Press, 1985: 403-35.

47 Nishida T, Miwa H, Shigematsu A, Yamamoto M, lida M, Fujishima M. Increased arachidonic acid composition of phospholipids in colonic mucosa from patients with active ulcerative colitis. Gut 1987; 28: 1002-7.

48 Sharon P, Stenson WF. Enhanced synthesis of leucotriene $B_{4}$ by colonic mucosa in inflammatory bowel disease. Gastroenterology 1984; 86: 453-60.

49 Weisner R, Troll W. Inhibitors of Poly (ADP-ribose) synthetase also inhibit proteases [Abstract]. Carcinogenesis 1985; 26: 121.

50 Scouvassi AI, Stefanini M, Lagomarsini P, Izzo R, Bertazzoni U. Response of mammalian ADP-ribosyl transferase to lymphocyte stimulation, mutagen treatment and cell cycling. Carcinogenesis 1987; 8: 1295300 . 